The Legal Position of Migrants in Denmark: Assessing the Context around the "Cartoon Crisis"

Adamo, Silvia

Published in:

European Journal of Migration and Law

Publication date:

2007

Document version

Early version, also known as pre-print

Citation for published version (APA):

Adamo, S. (2007). The Legal Position of Migrants in Denmark: Assessing the Context around the "Cartoon Crisis". European Journal of Migration and Law, 9(1), 1-24. 


\title{
The Legal Position of Migrants in Denmark: Assessing the Context around the "Cartoon Crisis"
}

\author{
Silvia Adamo* \\ Ph.D.-Fellow, Faculty of Law, University of Copenhagen
}

\begin{abstract}
What can we infer from the legal status of migrants living in Denmark? This article argues that understanding recent developments in Danish immigration law is essential for comprehending contemporary political tensions in this policy area, including notably the cartoon incident. The analysis offered focuses on general principles and practical notions of Danish immigration and refugee law, integration policies and regulations in light of international legal obligations, rules on family reunification, and the growing importance of citizenship status and anti-terrorism measures.
\end{abstract}

\section{Keywords}

Rights of migrants; Immigration Law; Citizenship Law; Integration policies; Denmark.

\section{Introduction}

In September 2005, a Danish newspaper published a series of 12 cartoons depicting the Muslim prophet Mohammed. The objective of this publication was to draw attention to the limits of freedom of expression in Denmark, following up on the case of a Danish writer on Islam, who had in fact been refused to illustrate his book as several illustrators felt pressured against it. ${ }^{1}$ After that, a national debate took place where on one side, a part of the Muslim community (along with the ambassadors from Muslim countries in Denmark) felt the need to express their discontent with the choice to portray the prophet. On the other side, the chief editor of the newspaper and the culture editor of the article defended their right to freedom of

*) The author completed the research while being a Visiting Scholar at the Department of Philosophy, Queen's University, Kingston, Ontario during 2006. This article is a revised version of a report on the legal status of migrants in Denmark that has been submitted at the XXVII World Congress of Comparative Law in Utrecht, The Netherlands in July 2006. Deep appreciation to the Danish Committee for Comparative Law for inviting me to write and present the national report. Warm thanks are also due to Rass Holdgaard, Bjørn Dilou Jacobsen and Kerri Aikman for their valuable comments on earlier drafts of this article. The references for the national legislation are as of September 2006; the minor changes in the numbering of the specific sections did not modify the essential structure of the regulations here examined and already in force at the time of the events.

1) The Islamic religion does not admit the representation of images of the prophet Mohammed, and several Muslim communities have therefore condemned the cartoons as an iconoclastic expression. 
expression, sustained in this view by the Danish government. On the international level this generated the worst crisis in Danish foreign affairs since World War two, with attacks on Danish embassies in various Muslim countries and a boycott of Danish products that have substantially affected the foreign revenue of a number of national industries.

In the aftermath of these events, it is of core interest to review the conditions under which migrants are admitted and live in Denmark. This article will present the legal issues related to this matter in order to provide a tool to better understand the background of what has been referred to as the "cartoon crisis". I will argue that the general conditions that regulate the migrants' legal status in Denmark have created a situation of tension that fuelled the political discussion. The comments on this affair have mostly insisted on the issue of the freedom of expression. ${ }^{2}$ In this article I will concentrate on the participants in Danish society that were brought into focus as challenging this freedom with their presence in the country. I will also argue that the nationality of the migrants has a substantive relevance in determining the conditions under which aliens are admitted and live in Denmark. This fact gains relevance when the national immigrant group also (coincidently) represents a religious minority, as the rules in force will undoubtedly affect a religious group, along with an immigrant group. Finally, I will show how the complexity of the statutes on immigration law impedes the development of a transparent legal practice.

The article is organized as follows. After a brief introduction of the general lines of immigration law, I will explore the connections between the international and the national set of rules. Next I will present the key legal concepts in Danish immigration law, examining in detail the rules that regulate the acquisition of the status of refugee and immigrant, and the rights that the migrants (immigrants and refugees $)^{3}$ may enjoy during their stay in the country. In the end of the article I will describe the relation between the migrants and the Danish labour market and the relation between the migrants and the state protective measures. The aim of this presentation is to offer different angles of view on the actual legal situation of migrants in Denmark.

\section{The Danish Approach to Migration Issues}

To understand the specific regulation on immigration in Denmark it is essential to place it in a broader picture of general policy lines of migration issues, which will be

\footnotetext{
2) See for example R. Dworkin, The Right to Ridicule, The New York Review of Books, nr. 5, 23 May 2006.

3) In the article I will assume that there is a semantic difference between the term "migrant", referring to an individual who moves from a country to another, and "immigrant", a term that characterises a person who comes to a country where she is not born in order to settle there. Personsgranted the status of refugee do not voluntarily move but are relocated in another country to provide them international protection. The term migrant will then for the purpose of this article cover both refugees and immigrants.
} 
hereby briefly sketched. The legal status of migrants in the Danish legal system is defined according to a general scheme of control of migration flows. Since the beginning of the XX century the legislation has been based on a system of residence permits and ongoing control with the requirements which migrants must meet in order to be renewed the permission to stay in the country. Since the early 1970's, after the introduction of an immigration stop, the regulation has been shaped in order to establish a more selective control system of immigration. ${ }^{4}$ In recent years, immigration and integration issues have featured high on the political agenda and have been the object of frequent legislative action. Denmark has traditionally perceived itself as a small nation-state with a high degree of cultural homogeneity, but this view has been challenged by the presence of immigrants and refugees with different ethnic and religious origins during the last few decades. 5 This confronts the Danish institutions and population with a diversity that had been previously unknown and that involves cultural and social reflections on the current state of the country and the policies that have to be adopted to adjust the society to a differentiated population. The consequences of this are, on one side, an increased debate on migrants' issues and, on the other side, an escalating detailed regulation on migrants' legal status (rules for integration, asylum, naturalisation, access to welfare benefits, possibility for family reunification and so on), the latter resulting in rules that may be difficult to access for the individual in question as well as for the administrative authorities. The study of the rules in force thus plays a crucial role in managing the issues of integration and status of migrants in the Danish society.

\section{International and National Legal Framework for Regulation of Migrants' Status in Denmark}

The aim of this section and of the next is to present the legal framework for regulation of migrants' issues in Denmark. As I will show, the overall picture that can be drawn from a very basic introduction to the legal background on the matter is that of a complicated enterprise. The regulation of migrants' status in Denmark is a fragmented system comprising different sets of rules of international law, EU-law, and national law. As a sovereign state, Denmark has the right to decide which foreign citizens can enter the country and eventually be eligible to obtain a residence permit. This principle is, however, modified by international rules concerning asylum and protection of family life. Moreover, the Danish membership of the European Union considerably restricts Denmark's freedom to regulate migration.

A common international set of rules on asylum and family reunification has not yet been implemented. Denmark, as with other countries, is therefore not directly

5) Thematic framework of AMID, Academy for Migration Studies in Denmark. 
obliged to grant a residence permit to neither asylum seekers nor family members who want to be reunified with a person residing in the Danish territory. However, the existence of various international legal instruments on these subjects indirectly commits Denmark to the protection of certain categories of individuals who seek asylum and to the protection of family life. ${ }^{6}$ The rules in force on asylum are to be found in the interplay between the UN Convention relating to the Status of Refugees, ${ }^{7}$ the UN Convention against Torture and Other Cruel, Inhuman or Degrading Treatment or Punishment ${ }^{8}$ and The European Convention on Human Rights. These sets of rules identify the situations in which an individual can apply to be recognized as a refugee in Denmark, but do not bind to the granting of asylum. Moreover, the status of the asylum seekers is determined by the national legal context in respect of the non-refoulement principle of international law. ${ }^{10}$

International regulations specify also the cases in which the Danish state is obliged to review an asylum claim. In the European Union, the Dublin- convention $\mathrm{II}^{11}$ is the framework that determines a series of criteria according to which Member States are responsible for the processing of asylum claims made in the EU by nonEU nationals. Denmark has an "opt-out" on the Justice and Home Affairs area in the EU co-operation and is therefore not bound by this convention but only by the previous convention, the 1990 - Dublin Convention. ${ }^{12}$ In short, this Convention sets up procedures, criteria and administrative rules with the purpose of determining the State responsible for examining asylum applications lodged in one of the Member States. It has been remarked that the original Dublin convention has not entirely met the expectations of combining and realizing Member States' concerns with asylum seekers' needs. ${ }^{13}$ Nonetheless asylum applications filed in Denmark will be evaluated following the guidelines in the original convention.

6) The Think Tank on Integration in Denmark, Background Report on Immigration and Integration Policies in Denmark and Selected Countries, Ministry of Refugee, Immigration and Integration Affairs, February 2004 .

7) Adopted on 28 July 1951; Protocol relating to the Status of Refugees from 4 October 1967.

8) Adopted and opened for signature, ratification and accession by General Assembly Resolution 39/46 of 10 December 1984.

9) Convention for the Protection of Human Rights and Fundamental Freedoms of 4 November 1950 and Protocol No. 6 to the Convention for the Protection of Human Rights and Fundamental Freedoms concerning the Abolition of the Death Penalty of 28 April 1983.

10) Art. 3 in the ECHR and art. 3 in the UN Convention against torture.

11) Council Regulation (EC) No 343/2003 of 18 February 2003 establishing the criteria and mechanisms for determining the Member State responsible for examining an asylum application lodged in one of the Member States by a third-country national.

12) Convention determining the State responsible for examining applications for asylum lodged in one of the Member States of the European Communities - Dublin Convention. Official Journal C 254, 19 August 1997 pp. 0001-0012.

13) As shown in the comparative study conducted in 1991 by the Danish Refugee Council: The Dublin Convention - Study on its implementation in the 15 Member States of the European Union, January 2001. 
Regarding the right to protection of family life, the international rules applying in Denmark stems from the two UN conventions from 1966 on Civil and Political Rights and on Economic, Social and Cultural Rights, the UN convention on the Rights of the Child (from 1989) and from articles 8 and 12 of the European Convention on Human Rights. These international agreements require the granting of permission to enter and reside within Danish territory if a rejection would hamper the maintenance of family life. ${ }^{14}$ Within the European Union, a Council Directive from September 2003 has introduced common rules for family reunification. ${ }^{15}$ However, as a result of the aforementioned reservation on the Justice and Home Affairs, Denmark is not obliged to implement the directive.

In the European Union, the freedom of movement and establishment of persons stipulates that citizens of the Union can move and take up residence in any Member State. ${ }^{16}$ The original concept of freedom of movement reserved to workers has developed into a fundamental right for all citizens of the Union through Community legislation, rulings of the European Court of Justice, ${ }^{17}$ and with the introduction of the notion of European citizenship in article 18 EC. The Member States have hereby renounced part of their sovereignty by forfeiting the decision over who can be allowed to enter their territory. The latest directive ${ }^{18}$ on the rights of citizens of the Union and their family members to move and reside freely within the Union consolidates into a single instrument the two regulations and nine directives that have governed the matter up until present day. The scope of introducing this new regulation is to support and encourage the free movement of Union citizens through the reduction of administrative formalities, clarifying the conditions to be met in order to exercise the right to stay for more than six months in another Member State and limiting the restrictions on the right to entry and the right of residence. The deadline for transposition in the Member States was 30 April 2006.

In regards to Danish law, the Aliens Act in force ("Udlandingeloven") ${ }^{19}$ is the main source of national regulation on the migrants' legal status. The Act regulates almost every step in the course of a foreigner's arrival and stay in Denmark and contains rules on granting of working permission, family reunification, extension and termination of residence permit, expulsion and exchange of information between

\footnotetext{
14) L.B. Christensen et al., Udlandingeret (2006).

15) Council Directive 2003/86/EC of 22 September 2003. See note 48 on the same matter.

16) The freedoms of movement and establishment for persons were already mentioned in art. 48 (now art. 39 EC) and art. 52 (now art. 43 EC) of the Treaty of Rome, but originally included only workers. They are now enshrined as rights for all citizens of the Union in art. $18 \mathrm{EC}$ after the introduction of European citizenship in the Treaty of Maastricht in 1992.

17) See in particular case C-184/99 Grzelczyck, European Court Reports [2001] p. I-06193 and case C- 413/99, Baumbast, European Court Reports [2002] p. I-07091.

18) Directive 2004/38/EC of 29 April 2004, adopted by means of co-decision procedure between the European Parliament and the Council.

19) Aliens Consolidation Act (Bekendtgørelse af udlendingeloven) nr. 945 of 01/09/06, subsequently referred to in the text as Aliens Act.
} 
authorities in the administration of aliens' cases. Connected to the basic law there are a number of other laws and regulations that are supplementing the issue of migrants' legal status. The Integration Act, The Active Social Policy Act, The Nondiscrimination Act, The Equal Pay Act, The Health and Safety at Work Act and numerous other connected regulations altogether define the migrants' legal status in terms of rights and duties, and clarify the labour conditions that are valid for immigrants and other residents in Denmark. ${ }^{20}$

After access to the country, aliens are subject to the same set of rules as Danish citizens by virtue of the principle of equal treatment which is valid in Danish law. This basic assumption needs to be qualified. Some examples of difference of treatment are to be found in the set of laws for accessing social benefits that can only be obtained after a substantial period of stay in the country. For instance, when a person is granted a lawful residence permit in Denmark, she will be comprised by the national health system and may enrol in an educational program, but will not be eligible for any financial support from the state unless she engages in a working activity or she obtains a permanent residence permit. The State Education Grant and Loan Scheme (SU, "Statens Uddannelsesstotte"), which supports the Danish students during their higher education, can only be granted to a foreign citizen if the applicant or the applicant's parents have been working for a number of years in Denmark. Nonetheless, the SU can be granted when the foreigner's permission of stay becomes permanent. For family-reunited persons, who have been granted a time-limited permission to stay and are relying on the fact that a reference person would support them in Denmark, the access to social benefits beyond those provided in the Integration $\mathrm{Act}^{21}$ is precluded. In addition to social benefits, the access to some other category of rights can also vary substantially for foreigners compared to Danish nationals. For instance, if one is not a Danish or Nordic citizen, or a person that has been granted the status of refugee, one shall have had permanent residence permit for three years before being able to apply for family reunification. ${ }^{22}$ There are many examples of rules affecting either immigrants or refugees' status that indicate that difference of treatment on grounds of nationality, against which no international human rights convention provides protection, also finds its place in Danish regulations.

In summary, the Danish regulation on migration issues is not only a matter of national sovereignty. There is a necessity to continuously adapt the national legislation in order to meet the requirements posed by international obligations, being these EU-directives or the rulings by the European Court of Human Rights. The administration of the rules in the cases where the national statutes are intertwined with international law and European law is thus becoming increasingly complex.

\footnotetext{
20) See section 4 in the following.

21) See section 4 in the following for a deepening of the scope and extent of this particular act and its implications for migrants' legal status.

22) Section 9 (1) 1-d of the Aliens Act.
} 


\section{Key Legal Concepts in Danish Immigration Law}

As above-mentioned, the main source of legislation on migrants' legal status in Denmark is the Aliens Act. As the name indicates, this act is concerned with the legal status of aliens in general. It is necessary to distinguish between two kinds of migrants/aliens: immigrants and refugees. These two categories of aliens are subjected to different regulations and it is therefore important to identify how the Danish law characterises these individuals who arrive in the country as either asylum-seekers or economic migrants. Eventually, these groups, when allowed to stay in the country, will constitute the heterogeneous community of migrants the Danish society is presently confronted with. In the following, I will analyse first the case of refugees and then that of immigrants.

\subsection{Refugees}

With regard to refugees, the Aliens Act defines the legal status of those individuals falling within the international regulation on refugee protection by identifying four distinct categories of refugees that are recognized by the Danish authorities. If an asylum seeker is recognized to fall into one of the following four categories, she will be granted a temporary permission to stay in the country, assigned a municipal authority to live in and be included in an integration program. The content of this process will be reviewed below.

Convention refugees are defined in the Danish Aliens Act according to the definition of refugee as stated in the UN Convention relating to the Status of Refugees. ${ }^{23}$ Following article 1 of the Convention, an individual currently outside her country of origin can be recognized as a refugee by Danish authorities in presence of "a well-founded fear of being persecuted for reasons of race, religion, nationality, membership of a particular social group or political opinion”. Since the Convention only safeguards those asylum seekers who fulfil the specific conditions in the Refugee Convention, additional national instruments and international practices have simultaneously been applied in order to supplement the Convention. From 1983 to 2002, Denmark recognized the legal notion of "de facto refugee", and has since replaced it with a protection status for refugees. ${ }^{24}$ The new supplementary model comprises those asylum seekers that do not fall under the refugee convention definition, but who nonetheless are at risk of the death penalty, torture, inhumane or degrading treatment or punishment if they return to their country of origin. The risk of individual persecution must be objective and well documented, while the more subjective fears for abuse or assault are no longer admitted to provide a sufficient basis for the need of protection. When the bill was introduced, it was stated that one of the 
main reasons was to reduce the number of immigrants arriving to the country, ${ }^{25}$ and it was debated whether the new, narrower, legal concept of protection status could have an effect or whether global tendencies had a stronger impact on the actual number of asylum seekers arriving in Denmark. ${ }^{26} \mathrm{NGO}$ organizations have recently held that there is considerable reason to assume that the change in the legal notion caused a significant fall in the granting of residence permits to asylum seekers in Denmark. ${ }^{27}$

Another category of refugees is that of quota refugees. These are refugees residing outside of Denmark who are relocated in the country after an agreement with the United Nations High Commissioner for Refugees or other international agreement. ${ }^{28}$ Denmark has agreed upon a quota of 500 placements of UN refugees per year. The provision on this category of refugees has recently been changed ${ }^{29}$ so that it now specifies the criteria applicable in the selection of quota refugees. The selection of quota refugees to relocate in Denmark shall, if possible, take into consideration the potential to settle in the country and to benefit from the residence permit on account of the asylum seekers' language skills, education, working experience, family ties and network, age and motivation. These conditions are supposed to enhance the rate of integration of refugees in Denmark as they may lead to the selection of individuals who, once relocated, will be more likely to learn the Danish language and participate actively in the labour market. The legislators may not have considered whether this purpose collides with the overall intent in international refugee regulation of providing protection to persecuted individuals, rather than protection of the recipient state's interests.

In extraordinary cases, the Ministry of Refugee, Immigration and Integration Affairs can grant a temporary residence permit on humanitarian grounds to an asylum seeker who has received a rejection of her application for asylum. ${ }^{30}$ The application of this rule is limited to exceptional cases only, and the grant of the residence permit relies on a concrete review of the applicant's case. Specifically, the rule is applied in presence of persons suffering from a serious physical or psychological illness, or if the return to their country of origin would aggravate a severe handicap. In

25) K. Kjær, Afskaffelse af de facto-begrebet - fup eller fakta?, Juristen nr. 1, 2003.

26) A. Henriksen, Udlandingelovens $\$ 7$, stk. 2. Svaret er fakta, Juristen nr. 2, 2004 and further comment by K. Kjær, Om den nye B-status. En kommentar, Juristen nr. 6, 2004.

27) The Danish Refugee Council has been evaluating the last three years of practice in this area, deducing that especially two groups of refugee that before 2002 were granted residence permit are now not recognised as refugees. Namely on the one hand Somali nationals fleeing from war-ravaged territories (from $98 \%$ of granting of residence permit in 2001 to $12 \%$ in 2004) and on the other hand hardly traumatized persons that previously have been tortured or sexually assaulted in a country where the political situation has been stabilized. See publication Artikel 1a nr. 1/2005, Danish Refugee Council and ECRE Country Report 2003: Denmark. For a description of the composition and work carried out by the Danish Refugee Council, see note 36.

28) Section 8 of the Aliens Act.

29) By means of Law nr. 403 of 01/06/2005.

30) Section 9 (b) of the Aliens Act. 
some cases families with small children who come from war-ravaged or famine areas, or persons that have been living in Denmark for many years during a lawful asylum process, can come into consideration for a residence permit based on humanitarian grounds.

The total number of granted asylum has been decreasing during the last years. ${ }^{31}$ This is a general trend in the Nordic countries (Denmark, Finland, Norway and Sweden), with a reduction of approximately 26\% from 2004 to 2005. As stated above, it is debatable whether the decrease is evidence of a global trend that has reduced the number of asylum seekers arriving to the European countries in general. However, there is evidence in the preparatory work of the laws and in other regulations regarding the conditions for the life of the refugees in the country of an increasing restrictive policy on asylum in Denmark. For instance, in 2002, new rules had been adopted regarding the basic amount of welfare ${ }^{32}$ following which an alien applicant must have stayed 7 years in Denmark before being entitled to the full amount of social welfare. Refugees are then entitled to a "start-help", which results in a considerably lower amount than welfare benefits for Danish citizens. The goal pursued with its introduction was a tool to motivate new refugees in the country to seek self-support through work. Since the rules also apply to those Danish citizens who come back to live in the country after a long period of stay abroad, the government sustains that they are not discriminating. Of another view are the Danish Refugee Council and the UHNCR, which have criticized the start-help for being in violation of art. 23 of the Refugee Convention. ${ }^{33}$ Other legislation on issues of integration, as the compulsory rules on housing outside ghetto-areas for refugees, ${ }^{34}$ are evidently tailored for a specific group in the society, with the unfortunate consequence of stigmatising refugees with negative connotations. ${ }^{35}$

To note also is the shift in the involvement of the Danish Refugee Council ${ }^{36}$ in the Danish asylum procedure. The Danish Refugee Council advises asylum seekers in the so-called manifestly unfounded cases, and previously it could also nominate

31) In 2005, of the approximately 2.260 asylum applications that were filed, the Danish Immigration service decided to review about 1.280 cases according to the Dublin procedure, and among these $17 \%$ of applicants were granted asylum. Data available on the Danish Immigration Service's website, at www.nyidanmark.dk.

32) The so-called "starthjelp" is regulated in the Active Social Policy Act and in the Integration Act.

33) The Article prescribes that "The Contracting States shall accord to refugees lawfully staying in their territory the same treatment with respect to public relief and assistance as is accorded to their nationals." The Danish Refugee Council sustains that the poverty created without real opportunity for work creates a new group of proletariat and places refugees in Denmark in a weaker position then in the rest of Europe.

34) New rules give the municipal authorities the possibility to refuse to admit persons on basic welfare or the start-help to live in the housing areas that are usually offered by the same authority to persons on a low income. This because immigrants or refugees on a low income have in the latest years grouped together in the same neighborhood. The government policy on this area sustain that migrants in this complexes are "not in contact with Danish language and culture" and presumably this hinders their "social and ethnical integration". See government policy action: A new chance for everyone, and more on the same policy in section 4 .

35) See the comment of Professor K. Ketcher in Artikel 1a, nr. 02/2005.

36) The Danish Refugee Council (Dansk Flygtningehjalp) is a private, humanitarian and independent organization that operates as an umbrella organization with 33 member organizations. Since 1956 the 
members for the Refugee Appeals Board (the appeal body for decisions on asylum cases), providing background information and documentation from the asylum seekers' native country, especially about the risk of persecution. In the 2002 Aliens Act reform, the composition of the Board was reduced, with representatives of the Danish Refugee Council and the Ministry of Foreign Affairs being removed. Currently, the members of the Board are appointed by the Ministry of Justice, the Ministry for Refugee, Immigration and Integration Affairs and the Council of the Danish Bar and Law Society. ${ }^{37}$ Human rights organizations regret this removal of civil society representatives specialized in refugee protection issues from the asylum procedure. ${ }^{38}$

To sum up, with a critical look on recent changes on the definition of the refugees' status in Danish legislation it is possible to identify some trends that come across as adverse to the refugee population in Denmark. The decision to reduce the number of refugees in the country and the constant focus on integration of the refugees (potential and of those already in the country) by a system of incentives through monetary punishments contributes to the depiction of refugees as unwanted in the Danish society. A consistent part of the laws which target the integration of refugees also includes immigrants, or at least some categories of immigrants, a description of which is addressed next. ${ }^{39}$

\subsection{Immigrants: A Typology}

In this section I will explore the rules that are in force in the Danish Aliens Act regarding immigrants. In contrast to refugees, immigrants choose to enter Denmark for a number of different reasons that are not linked with a need for protection from persecution. When they later decide to establish themselves in Denmark, and before they obtain Danish citizenship, they constitute a heterogeneous immigrant group of different nationalities.

I will show in the following that nationality plays a key role in the determination of the legal status of immigrants, and that this assumption is based on the legal framework provided by the Aliens Act. These nationality distinctions determine in the first place the permission to enter the country and subsequently the possibility to work and apply for a permanent residence permit. ${ }^{40}$ By analyzing the Aliens Act we can enumerate three categories of immigrants based on their country of origin:

organization has been working for refugee protection and promotion of lasting solutions to refugees' problems based on human rights and humanitarian principles on both the national and international level.

37) Section 53 (2) of the Aliens Act as modified by Law nr. 365 of 06/06/2002.

38) The report of the Commissioner for Human Rights Gil-Robles from 2004 found that "it would be most desirable (...) for the Board's original composition to be re-established". CommDH(2004)12 p. 14.

39) The rules on family reunification for refugees do not differ substantially from the ones in force for thirdcountry nationals, and will therefore be reviewed conjointly in section 3.2.3.

40) The practical legal consequences of this nationality "classification" are discussed in the end of section 3.2.3. The authority in charge of administrating the procedures on this matter is the Danish Immigration Service, which is a directorate within the Ministry of Refugee, Immigration and Integration Affairs. 
- Nordic citizens: nationals of Finland, Iceland, Norway, and Sweden;

- EU-citizens: nationals of the Member States in the European Union (including the 10 new Member States from May 1, 2004) and European Economic Area citizens from Liechtenstein; in addition, a subcategory is constituted by the nationals of those countries with which the European Union has stipulated so-called association agreements;

- Foreigners coming from third countries.

Following up on these categories, I will compare the measures relating to the right of entry in Denmark, the possibility of obtaining a residence and working permit, and the right to family reunification. It will thus be clear that the differentiation in legal status between foreigners can widen significantly.

\subsubsection{Nordic Citizens}

The status of Nordic citizens living in Denmark does not present particular problematic assessments. As a consequence of the long-lasting Nordic cooperation on various legal matters, nationals of Finland, Iceland, Norway, and Sweden may enter and stay freely in Denmark without special permission. ${ }^{41}$ Nordic citizens can travel to Denmark without a passport. ${ }^{42}$ Nationals from these countries can therefore reside and work in the country on an equal footing with Danish citizens. The impact of the Nordic cooperation on foreigners' legal status is also noticeable in the rules governing the acquisition of citizenship, inasmuch as Nordic citizens have an easier access to Danish citizenship in respect to other nationals. ${ }^{43}$ There is no obligation to follow a particular integration program for Nordic citizens residing in Denmark, and that is also attributable to the fact that these individuals share with the Danes not only a resemblance in their mother tongue but a common Scandinavian culture as well. Beside the long-standing cooperation between borders, it is debatable whether the shared culture is one of the reasons to provide for an almost completely equal treatment between Danish and Nordic citizens in Denmark.

\subsubsection{European Citizens}

According to the rules on free movement of persons and services in the European Union, the possibility to enter and stay in Denmark for European citizens is open, but time-limited to three months, or in case of entry for pursuing work, to a six month period. ${ }^{44} \mathrm{EU}$ citizens are required to carry an identity card or passport in order to be able to show their identity and citizenship to Danish authorities upon request. In case of extension of stay beyond three or six months, EU citizens must

\footnotetext{
41) Section 1 of the Aliens Act.

42) Other documents as driving license or bank cards can be used upon request for identification.

43) Section 3 of the Citizenship Consolidation Act 422 of 07/06/2004 (Bekendtgorelse af lov om dansk indfodsret).

44) Sections 2-3 of the Aliens Act.
} 
apply for an EU residence certificate, which is a certification of the rights accorded in virtue of the freedom of movement and establishment in the European Union, and therefore differs from a residence permit that follows the conditions and rules laid down in the Danish Aliens Act. The residence certificate is granted when an EU citizen is either actively employed (has a paid job, is running an independent business, or offering services of commercial nature), or is a student actively enrolled in a accredited degree program (upon the condition of being financially self-sufficient) or finally, where she has sufficient assets or earnings to support her stay in the country (equal to the level of welfare aid provided in Denmark).

Thus, no residence permit is required upon entry for EU citizens, with the exception of citizens of some of the new Member States. In the aftermath of the EU enlargement which took place in May 2004, a transitional plan has been adopted to ensure a gradual shift towards free movement. ${ }^{45}$ This involves that at the moment nationals from some of the new Member States of the EU (Estonia, Latvia, Lithuania, Poland, Slovakia, Slovenia, The Czech Republic and Hungary) are required to obtain a residence and working permit prior to entry in Denmark, in accordance with some more specific transitional regulations. ${ }^{46}$ The work permit can only be granted in the case of the applicant holding fulltime employment on collective bargaining contract conditions, or under standard wage and work conditions. A specific offer of employment or signed employment contract is required, and the employer must be registered in compliance with the Danish Tax at Source Act. ${ }^{47}$ The work permit is revoked if the worker is no longer engaged in a working activity, or if the terms of employment change.

In regards to the right to family reunification for European citizens, as abovementioned, the European Council Directive on the right to family reunification ${ }^{48}$ is not in force in Denmark, since the country has an opt-out on the European legal cooperation. Nonetheless the obligation to respect family life derives from the principle on freedom of movement and establishment. The principle is embodied in various directives and rulings from the $\mathrm{EC}$ court. ${ }^{49}$ The aforementioned transitional plan for new EU citizens requires that these applicants must provide housing compliant with Danish standards. Family members of other EU citizens pursuing work in Denmark can stay in the country up to six months, or three months if the stay is not work-related. Nevertheless, a visa must be obtained if the family member comes from a country with a visa requirement.

\footnotetext{
45) Section 9 (a) of the Aliens Act.

46) Sections 6 and 9 (a) of the Aliens Act.

47) Section 9 (a) 6 of the Aliens Act.

48) Council Directive 2003/86/EC of 22 September 2003, OJ L 251 of 03/10/2003. The directive has the expressed purpose of harmonising national legislation in the European Union in order to ensure fair treatment of third country nationals, and to develop a more intensive integration policy between immigrants lawfully residing in the EU by means of active and uniform protection of the right to family reunification. 49) See for example Case C-60/00, Carpenter v Secretary of State for the Home Department [2002] p. I-06279, which may have significance for the general interpretation of Art. $8 \mathrm{ECHR}$.
} 
Here it is also important to mention the international agreements that the European Union has stipulated with third countries, as they give rise to a different status for certain nationals in Denmark. The association agreements that the Community may conclude with one or more States or international organizations involve "reciprocal rights and obligations, common action and special procedure". ${ }^{50}$ The establishment of an association entails a special relation to the European Community that has consequences for the nationals of the third countries involved, and that have direct effect in the Danish legal order. The Ankara-agreement from 1963 is an association agreement with Turkey whose purpose is to promote a strengthening of the economical and trade-related relationships between this country and the EU. In practice, this agreement means that there cannot be any discrimination on the basis of nationality for Turkish citizens living in the Union. ${ }^{51}$ In the case of Denmark, this imposes limits on the legality of measures that requires Danish citizenship, for example, in order to practice a specific profession. Turkish citizens have a right to stay in the Member State where they lawfully engage in a working activity and to be included in the social regulations for workers that are in force in the country of stay. ${ }^{52}$ As regards the rights of family members of Turkish immigrants, the Member States maintain their right to regulate the rules on family reunification. Switzerland has also a range of agreements with the European Union that involve a gradual opening to free movement of Swiss and European citizens. This is sought by the introduction of measures that give access to entering the European and Swiss labour market, permission to enter and reside in the respective countries and approximation of laws on social issues. Finally, the European Union has a series of agreements with Bulgaria and Romania in order to provide a gradual approach to the Community's legal order. This means that lawfully employed workers from these two countries are provided protection against discrimination on grounds of nationality.

The conditions under which European citizens live in Denmark resemble the conditions stipulated for Nordic citizens. European citizens generally do not experience particular difficulties in acceding the country or the labour market. Nevertheless, some issues of administrative character differentiate their status from that of the Nordic citizens. As in a figure of concentric circles, the treatment of citizens from Nordic countries is practically on an equal basis with Danish citizens, with absence of particular regulation especially designed for these legal subjects, and followed by the European citizens, whose rights are acknowledged and protected by European law. For nationals coming from outside the European Union the rules to

\footnotetext{
50) Article 310 of the Treaty establishing the European Community, Official Journal C 325, 24 December 2002.

51) Article 9 of the agreement refers directly to the prohibition against discrimination on grounds of nationality in the Treaty establishing the European Community. Turkish citizens constitute the major immigrant group in European countries.

52) H. K. Nielsen, EUs associeringsaftale med Tyrkiet og dansk erhvervs- og arbejdsret, EU-ret og Menneskeret Nr. $3 \& 4 / 2000$.
} 
follow in order to enter and stay in Denmark are far more complex, as I will show in the next section.

\subsubsection{Third-Country Nationals}

Foreigners, who are not EU or Nordic citizens, also called third-country nationals, can be grouped into nationals coming from a country with a visa requirement and nationals coming from a country without a visa requirement. Nationals who are coming from a country with a visa requirement must apply for a short-term visa in order to enter Denmark. For those nationals arriving from another Schengen country, new common rules have been introduced to render possible the freedom of movement within the Schengen area; in some cases a visa is required for a period no longer than three months. ${ }^{53}$ The visa requirement is applied to control the flow of migration for entering and residing within the Schengen area. There is no harmonisation in the Member States practice of granting of visa in Europe, though an EU Council regulation listing the countries whose citizens are required to hold a visa has been in force since $2001 .^{54}$

Since 2004, a new visa administration system has been in force in Denmark. ${ }^{55}$ The new administration of visa rules is oriented towards rejection of visa applications where a concrete and individual evaluation of the applicant's tie to the country of origin does not exclude that she would (try to) extend her stay in a Schengencountry after the expiry of the visa. A visa is, by definition, granted only for a limited period of time, whilst an individual who has intention to reside in Denmark for a longer period must apply for a residence permit. If there is reason to suspect that a person coming from a country with a visa-requirement may later seek permanent or long-term residency in Denmark, her application for a visa will not be accepted. The same is valid in the case where the applicant poses a threat to national security. A waiting period ("karensperiode") is introduced to prevent abuse of visa, so that the applicant cannot get a new visa for three to five years, depending on how long the visa was overstayed.

Pursuing the new visa administration system, the immigration authorities have divided the countries with a visa requirement into three country-groups: an asylum group, an immigration group and a tourist group. The group classification is based on a general evaluation of the index of "immigration-risk" that applicants from the various countries will seek to extend their stay after the visa-period, either in Denmark or in another Schengen country. Different guidelines for a visa issuance apply

\footnotetext{
53) Section 2 (b) of the Aliens Act.

54) Council Regulation (EC) No 539/2001 of 15 March 2001 listing the third countries whose nationals must be in possession of visas when crossing the external borders and those whose nationals are exempt from that requirement.

55) Memorandum from the Ministry of Refugee, Immigration and Integration Affairs, 29 September 2004 (Notat om visumpraksis galdende fra den 1. Oktober 2004), replaced but not substantially changed in September 2005 (Notat om visumpraksis galdende fra den 1. Oktober 2005).
} 
to the three country-groups so that there is a very strict practice in granting visas to applicants coming from countries listed in the asylum group, while a "certain connection" 56 to a person in Denmark can be required to nationals in the immigration group. Citizens coming from the countries listed in the tourist group are generally eligible for purely tourist-related visits.

The basic requirements to be met in order to obtain a visa entail that the applicant must hold a valid passport; have necessary funds during the stay and for the return trip; hold a travel-health insurance policy (covering all the Schengen countries and with a minimum coverage of 30.000 Euros); not be registered as undesirable in the Schengen Information System (SIS) and not be listed on the Danish entry ban list. ${ }^{57}$ Entry into Denmark as a national of a third country is then a much more complicated enterprise than for citizens of the EU or the Nordic countries. Although, the differences in treatment do not stop here.

The regulation of the rules on family reunification on grounds of marriage or registered partnership for third-country nationals is even more complex and still constantly being revised. In the last couple of years, the Danish government introduced significant restrictions on the right to family reunification that have affected particular groups of immigrants and especially refugees. The new legislation has been drafted with a double aim: on the one hand to counter the practices of proforma (arranged) and forced marriages,${ }^{58}$ and on the other hand to restrict the number of aliens in Denmark for the good of the integration of the immigrants already in the country. ${ }^{59}$ These restrictions have accomplished the desired outcome of reducing the number of persons granted family reunification, which was almost halved from 2002 to $2003 .^{60}$

The requirements that must be met are currently as follows:

- a minimum age of 24 years for both spouses/partners;

- it may not be considered doubtful that the marriage was contracted at both parties' own desire (marriage between close relatives or otherwise closely related parties may be considered doubtful), and there may be no definitive reason for assuming that the decisive purpose of contracting the marriage is to obtain a residence permit;

\footnotetext{
56) Visas to nationals of this group are granted to spouses, cohabiting companions, boyfriends/ girlfriends and fiancés, children irrespective of age, parents, siblings and their spouses, underage nieces and nephew and grandchildren, close acquaintances of previously foreign stationed Danes, sponsor children and older family members.

57) The entry ban list comprises those aliens who have been deported from Denmark and subsequently given an entry ban.

58) A pro-forma marriage occurs where there is reason to presume that the marriage or the cohabitating relationship was established with the main objective of achieving a residence permit. A forced marriage is defined as a marriage entered into against the wishes of one or both parts.

59) Draft bill LF $1522001 / 2$.

60) European Council Country Report 2003: Denmark.
} 
- the person residing in Denmark must prove that she disposes of her own dwelling of a 'reasonable size' and must prove that she is able to maintain the applicant;

- the person residing in Denmark must provide a financial security of 50.000 Danish kroner $^{61}$ (circa 6.700 Euros) to cover any future public expenses to support the spouse/partner;

- the person residing in Denmark may not have received public financial assistance for a period of one year prior to submission of the application for the family reunification;

- the person residing in Denmark may not have been sentenced to imprisonment or other criminal sanction involving or allowing deprivation of liberty for violent assault on a spouse or cohabitant within the last 10 years;

- the spouses'/partners' aggregate ties with Denmark must be stronger than the aggregate ties with any other country. The requirement of aggregate tie is not applied to persons who have had Danish citizenship or permanent residency in the country for at least 28 years.

The complexity and ambiguity of these conditions have given rise to a non-transparent and unpredictable administrative practice. This is partly due to the fact that the regulation is to be found in several different legal texts. The requirements are specified in the Aliens Act, ${ }^{62}$ whilst two additional conditions have been introduced in the Formation and Dissolution of Marriage Act, in the sections regarding the requirements the spouses must meet in order to marry lawfully. ${ }^{63}$ Furthermore, the Immigration Service drafted a series of internal memorandums that explain and clarify the various requirements for the use of the administrative personnel. In September 2005, these memorandums were published on the Immigration Service website after a critique of the system accused it of being arbitrary and a source of potentially random decisions on family reunification. It is in fact a rule, that all the requirements must be met; nevertheless, in some special cases a permit for family reunification can be granted even if some of the requirements are not met. It came to the knowledge of the public that the administrative authorities, for a period of a year and a half, had made an exception from the aggregate tie-rule and the 24 yearsrule for applicants with a particular tie to the Danish workplace. The Danish Centre for Human Rights invoked a publication of the cases to ensure equal treatment of

\footnotetext{
61) Amount required in the 2006 Aliens Act, but subject to rate adjustment.

62) Section 9 of the Aliens Act.

63) Sections 11 (a) prohibits marriage among foreigners that do not have a lawful residence permit in the country (e.g. asylum seekers that are awaiting in Denmark a decision on their application), while section 11 (b) entails that the spouses are aware of the rules of the Aliens Act on family reunification in order to contract the marriage. Formation and Dissolution of Marriage Act nr. 147 of 09/03/1999 (Lovbekendtgørelse om agteskabets indgaelse og oplosning) as modified by Law nr. 365 of 06/06/2002. For a critical review of regulating migrants' legal status through marriage laws, see A. Kronborg, Agteskabsbetingelser, Juristen nr. 3, 2005.
} 
the applicants to avoid breaches of international human rights obligations. ${ }^{64}$ In order to protect the principle of equality before the law and transparency of Danish administrative practice it is of major importance that the citizens are informed in a clear and understandable language of their actual legal status. ${ }^{65}$ Furthermore, the complexity of the rules on family reunification in Danish law collides with the rules on free-movement in the European Union, which may provide a better protection of the status of third-country nationals who are married with European citizens. This means that ingenious ways to get around the strict family reunification rules in Denmark have informally been developed in order to take advantage of the higher level of protection of family life bestowed upon European citizens. ${ }^{66}$ Though these procedures are legal by a strict definition, only few individuals would have the resources to resolve to their rights as European citizens. The creation of such informal practices is again a sign of inequality and unclear administration of family reunification cases.

The specificity of the conditions outlined has been evaluated to lead to indirect discrimination, affecting only certain, identifiable groups of the population. ${ }^{67}$ This came into focus under the visit of the Council of Europe's Commissioner for Human Rights in Denmark in 2004. ${ }^{68}$ Also, The United Nations Committee on Economic, Social and Cultural Rights noted, "with concern", the amendment to the Aliens Act raising the age for family reunification, concluding that it constituted an impediment to the country's obligation to guarantee the enjoyment of the right to family life in Denmark. ${ }^{69}$ However, it has been argued that the new rules on family reunification can indeed provide a protection for those migrant women coming from a patriarchal family background, where there would otherwise be little chance to stand against forced marriages. ${ }^{70}$

64) The Danish Center for Human Rights, Hvidbog om Agtefallesammenforing, 2005.

65) J. Christoffersen, Forvaltningsretlig transparens: Om familiesammenforing i praksis, Juristen nr. 2, 2006.

66) I am here referring to what is known in Denmark as 'the Swedish solution' and/or 'the Slesvig solution', both informal and non-codified procedures. Foreigners that are Danish nationals but who cannot nevertheless meet the requirements for family reunification in Danish law, have sometimes no other way out than to move to Sweden or Germany to be included in the European law provisions on the protection of freedom of movement. These latter entail the right for a working European citizen who takes up residence in another European country to bring along her family. Since no requirement on attachment to the country, minimum age, adequate housing and so on is present in other European regulations, it is in this way 'easier' to be family reunited with a third-country national, if that is the wish of the migrant.

67) The Danish Center for Human Rights, Udredning om Agtefellesammenforing, 2004.

68) See the concerns expressed in the Report by Mr. Alvaro Gil-Robles on his visit to Denmark, Office of the Commissioner for Human Rights, CommDH(2004) 12 of 8 July 2004 pp. 6-12, and the consequent Memorandum by the Ministry of Refugee, Immigration and Integration Affairs from 22 September 2004, assessing that Danish Law is not in violation of international obligations on human rights issues.

69) E/C.12/1/Add.102 of 14 December 2004, Consideration of reports submitted by State Parties under Articles 16 and 17 of the Covenant. The concluding observations encourage considering "alternative means of combating the phenomenon of forced marriage involving immigrant women" and taking "appropriate measures to either repeal or amend the so-called 24-year rule" (recommendation nr. 29).

70) S. Jørgensen, Om tvangsegteskaber som indgreb i kvinders rettigheder. Nye retlige design - Dansk ret under konkurrence, DJØF 2003. 
The eligibility conditions for family reunification with children have also been restricted, reducing the age limit from under-18 to under-15; children above 15 years are now only exceptionally granted family reunification. The motives behind these changes revolved around the eventuality of admitting children in Denmark that had not stayed in the country in the most influential years of formation, and who would therefore be less likely to adopt Danish values and culture. These provisions have been criticised for not protecting the children's right to be reunited with their parents, ${ }^{71}$ potentially leading to disruption of families with children of different ages. The possibility to have family reunification with parents of over 60 years of age, in force until 2002, is no longer admitted.

At this stage it appears clear that the range of rights bestowed upon immigrants can vary considerably. Foreigners that are willing to set up their dwelling in Denmark have easier access to the right of entry and establishment if they are Nordic or European citizens. Nationals of a third country generally experience more difficulties to enter and stay in Denmark and as we have seen, the possibility to be reunited with one's own family has been significantly restricted in the past few years. The improved situation for some categories of individuals (viz. nationalities) stems from the international cooperation on the freedom of movement that Denmark has carried out with other Nordic and European countries. It is debatable whether the individual subjects can distinguish between different legal contexts when they experience that, coming from a third country, they do not have the same extent of rights as Nordic and European citizens. It is also questionable whether it is possible to maintain an order that differentiates so largely between nationals without incurring discontent among the persons involved, especially when the wording of the preparatory work and the political debate refers to cultural problems of integration and assimilation as a primus motor of legislation.

\section{The Migrant and the Danish Labour Market}

Up until now, I have been revising the rules in force for access and stay in Denmark. Of major importance is, however, also to review the laws and policies that affect the access of the migrant to the labour market after entering the country. On the international level on this matter the United Nations Committee on Economic, Social and Cultural Rights has recently recommended that Denmark "continue strengthening programmes to reduce unemployment targeting the most affected groups, including immigrants and refugees" and also "that the State party adopt national policies to ensure that all families have adequate housing facilities and that adequate resources are allocated for social housing, particularly for disad-

71) European Council Country Report 2003: Denmark. 
vantaged and marginalized groups such as immigrants". ${ }^{72}$ Denmark, along with the other EU Member States, has not ratified the international Convention on the Protection of the Rights of All Migrant Workers and Members of Their Families (ICRMW). ${ }^{73}$

On the national level, the successful integration of foreigners in Denmark in recent years has been tied to an overall plan of increasing the immigrants' access to the labour market. This is sought by intensifying Danish lessons, offering more job training and by reducing financial support in order to motivate people to seek employment. The importance of the connection to the labour market can also be traced in other provisions concerning the status of foreigners in Denmark. For example, the general requirement for being granted a permanent residence permit is seven years of continuous stay in the country prior to the application. Nevertheless, an exception to this requirement can be made in respect to immigrants that have been actively employed, as to say have had permanent ties with the labour market as an employee or self-employed in Denmark. ${ }^{74}$

The participation in the labour market is generally considered by Danish authorities and policy-makers as being an important tool to integrate the migrants living in the country. On the one hand, being an active member of the workforce contributes to the polity, whilst on the other hand it also represents the possibility to improve the life conditions of the migrant and her family. Therefore, the legislation is shaped in a way to allow the migrant to enter the labour market as soon as possible. This is sought by means of integration programs (language courses and skill development courses); establishment of partnership agreement between municipalities and private firms and training of new employees sustained by matching and mentor arrangements. ${ }^{75}$ As late as June 2005, the Danish government presented a new plan on the policy strategies to adopt in order to support migrants' integration in Denmark. The proposal bears the name "A new chance for everyone" and suggests, among other things, several initiatives to facilitate migrants' access to the labour market, boosting education and employment offers, countering ghettoization in vulnerable neighbourhoods and preventing and combating crime (this last by means of tightening of expulsion rules).

The regulation applicable in this area is the Integration Act, together with the ministerial executive order on individual contracts. ${ }^{76}$ The purpose of this regulation

72) E/C.12/1/Add.102 of 14 December 2004, Consideration of reports submitted by State Parties under Articles 16 and 17 of the Covenant, Suggestions and recommendations nr. 26 and 34 .

73) Adopted by General Assembly resolution 45/158 of 18 December 1990.

74) Section 11 (4) of the Aliens Act.

75) Ministry of Refugee, Immigration and Integration Affairs, Inspiration for integration (2004).

76) Danish Integration Act nr. 902 of 31/07/2006 (Bekendtgorelse aflov om integration af udlandinge i Danmark) and Executive Order on individual contracts and introduction program in the Integration Act nr. 252 of 28/03/2006 (Bekendtgorelse om udarbejdelse af individuel kontrakt og om introduktionsprogrammet efter integrationsloven) from the Ministry of Refugee, Immigration and Integration Affairs. 
is to ensure that newly arrived aliens can exploit their abilities and resources with the aim of becoming participating and "yielding" citizens. The integration effort is realized by assisting the aliens' participation in the life of the society in terms of politics, economy, employment, social activities, religion and culture on an equal footing with other citizens; by making newly arrived aliens self-supporting quickly; and finally, by imparting to the individual alien an understanding of the fundamental values and norms of Danish society. ${ }^{77}$ The authority in charge of the integration of aliens is the local authority/municipality.

Each immigrant has to sign a contract with the local authorities where she is living within the first month of residence in the municipality, agreeing on her rights and obligations in regards to integration into Danish society, such as "the alien's responsibility to become self-sufficient through employment as soon as possible". ${ }^{78}$ The contract is individual in the sense that the particular situation of every immigrant is assessed in order to plan the most effective program for her. If a breach of contract occurs, i.e. if the immigrant does not respect the conditions agreed upon, the municipality may resort to sanctions in deduction of social security benefits (child support or other financial support).

The individual contract is a part of the obligatory 3-year integration program. During this time, the immigrant is offered gratis Danish classes that she must attend actively. A low participation in the class may result in a breach of the obligation of following the introduction program as stated in the individual contract, which can have further consequences for the immigrant. It is viz. a condition for the issuance of a permanent residence permit, that the alien has fulfilled her integration program as stated in the individual contract with the municipality. ${ }^{79}$

The rules in force for the integration of migrants are not applied to Nordic citizens or EU-citizens, but are valid for those asylum seekers who are granted a residence permit as refugees in Denmark. The Integration Act specifies that the Danish Immigration Service will decide where in Denmark the refugee will live (allocation of refugees). When a refugee is granted permission to stay, she will move to the municipality assigned to her and subsequently be offered an integration program by the local authority.

Almost every Western state has special immigration provisions for highly skilled migrants that can contribute to the national labour market and Denmark is not an exception to that rule. There is a general strain to attract and maintain qualified manpower in the country. In July 2002, special rules were introduced for residence and work permits granted on the basis of employment. These rules, also called the Job Card Scheme, have the purpose of rendering it easier for companies to obtain

\footnotetext{
Section 1 of the Integration Act.

78) Section 3 of the Executive Order on individual contracts and introduction program in the Integration Act.
}

79) Section 11 (9) 1 of the Aliens Act. 
work permits for foreigners with special qualifications within certain professional fields. In accordance to this, the Ministry of Refugee, Immigration and Integration Affairs has compiled a "positive list" of the professional fields that are lacking skilled manpower. ${ }^{80}$ Whereas in the evaluation of other working migrants the Danish Immigration Service usually requests a statement from the relevant trade union in order to assess whether the conditions for the granting of a work permit are fulfilled (i.e. if there are no qualified individuals currently residing in Denmark who can perform a specific job), in the case of an application within the fields of the positive list such a statement is not required. Instead, a residence and work permit will immediately be granted, provided that the applicant has a concrete job offer in line with regular Danish employment and salary conditions. The work permit granted in these cases is time-limited and only extended if the shortage of specially qualified manpower in the field persists. In 2006, new rules for an easier access to work in Denmark for foreign researchers have also been introduced. The effort to maintain skilled manpower in the country can also be traced in respect to highly educated students that achieve a degree in Denmark. Since June 2005, the Immigration Service has had the intention to change its standard procedures allowing a three-month extension of the student residence permit to give the most skillful students an extra period of time to seek employment in the country.

In accordance to this focus on labour as an integration tool for migrants in their new country of residence, migration policy has been oriented towards a further reduction of the possibilities to enter the country on other grounds than participation to the labour market. The results of this reasoning has had a kind of "spill-over" effect on the regulation of the legal status of refugees as well, with a consequent obligation to follow integration programs and as we have seen previously, by the introduction of new selection criteria for quota-refugees. It can be discussed whether individuals that are recognized as being in need for international protection have to fulfil the same requirements that the Danish state imposes on future immigrants. The general rhetoric of the political discourse does maintain that a well functioning, integrated and yielding migrant is a 'good migrant', which can cause the erroneous conclusion of considering people that do not possess these qualities as being 'bad migrants'. In doing this there is the danger of not taking into account the particular conditions of certain groups of migrants, as for instance people suffering from post traumatic stress disorder after the experience of torture and others who cannot be expected to have the capacity to integrate in the labour market with ease. The backlash of ignoring these circumstances in legislation regarding the status of migrants ${ }^{81}$

80) The list includes specialists as engineers, scientists in the natural sciences and technology sector, IT-specialists, doctors and nurses. The list is revised on a continual basis.

81) An example of this can be found also in the area of citizenship regulation. In December 2005 the language requirement that must be fulfilled in order to file an application for naturalization has been substantially raised. There is medical evidence of the fact that refugees with post traumatic stress disorder have difficulties in learning new languages. Nevertheless, the circular now in force explicitly states that individuals 
can result in high human costs for the individuals involved and a general perception of exclusion of disadvantaged foreigners from the Danish society.

\section{State Protective Measures}

Another area where the new legislative changes may affect the legal status of the migrants living in Denmark revolves around the so-called state protective measures. A number of Danish laws reflect the concern to protect the state from possible terrorist attacks. In 2001, the United Nations Security Council demanded and called upon all states to adopt rules to counter terrorism. ${ }^{82}$ In Denmark this has been followed up by the introduction of a bundle of measures to prevent terrorist attacks in the country (the so-called "terror-pakke"). The implications for the migrants' legal status can be found in the changes made to the Aliens Act which were introduced in 2002.

The most significant modification was the introduction of a new chapter opening for the possibility of exchange of information between the immigration authorities and the intelligence services and the prosecutor. ${ }^{83}$ The new rules stipulate that information on an alien may be passed between these public authorities without the alien's consent. It has been argued that measures of this kind present a conflict between two opposing considerations: on the one hand, the necessity to allow the control actions to protect state security and on the other hand the individual's interest in the protection of her liberty and the rule of law. ${ }^{84}$

Moreover, a new section on the refusal of issuance of residence permit ${ }^{85}$ now states that an alien cannot be issued a residence permit if the alien is deemed a danger to national security or a serious threat to the public order, safety or health; or is deemed to fall within Article $1 \mathrm{~F}$ of the Convention relating to the status of refugees. ${ }^{86}$

The possibility of expulsion ${ }^{87}$ of foreigners that pose a threat to state security has been expanded to include aliens that have been unlawfully residing in the country

suffering from this disease will not be eligible for an exemption from this requirement, even if their medical condition is "chronic and officially documented". See section 24 (3), note 4 in circular CIS nr. 9 of $12 / 01 / 2006$.

82) Resolution nr. 1373 of 28 September 2001.

83) Chapter 7 a, sections 45 (a)-45 (c).

${ }^{84)} \mathrm{K}$. Kjær, De udlandingeretlige elementer af FN's terrorresolution i dansk ret, EU-ret og Menneskeret nr. 5 , 2003.

85) Section 10 of the Aliens Act.

86) Art. $1 \mathrm{~F}$ prescribes that "the provisions of this Convention shall not apply to any person with respect to whom there are serious reasons for considering that (a) he has committed a crime against peace, a war crime, or a crime against humanity; (b) he has committed a serious non-political crime outside the country of refuge prior to his admission to that country as a refugee; (c) he has been guilty of acts contrary to the purposes and principles of the United Nations".

87) Section 25 of the Aliens Act. 
for less than six months. This could be the case of internationally known aliens that may carry on disturbing activities in the country (as in large demonstrations) or may pose serious threat to the public security and health (for example, by intervening in the preparation of chemical, biological, nuclear weapons or warfare agents). In the preparatory work for the draft bill, it was sustained that emergency measures to prevent terrorist action are commonly accepted in international law as a legitimate reason for expulsion of aliens. ${ }^{88}$ An important modification to the measure on expulsion derives from the international rules on prohibition of torture ${ }^{89}$ that lay a constraint on the possibility to send a person to a country where she would risk torture or other inhuman or degrading punishment..$^{90}$

A time-limited residence permit can always be revoked by the Danish Immigration Service if there is an alert in the Schengen Information System (SIS) issued for the purpose of refusing entry of the foreign national. ${ }^{91}$ This can occur if the foreigner has been reported as committing actions which are considered serious enough to warrant expulsion if carried out in Denmark, i.e. serious crime.

Involvement in terrorist related activities can also have consequences concerning the status of foreigners permanently living in Denmark. As a general requirement, criminal activity of a serious character can be an exclusion factor for applications for Danish citizenship. ${ }^{92}$ A new section introduced in June 2004 opens for the possibility to deprive a person of her Danish citizenship ${ }^{93}$ if she has violated the part of the penal code relating to state security and in so doing has posed a threat to the public order or health. ${ }^{94}$

In the issue of the state protective measures, it is extremely difficult to balance between the need for protection of the state public order and of safeguard of individual liberties without going down a politically dangerous "slippery slope". It is, nevertheless, necessary to monitor the legal changes that are introduced in this field to prevent them from pointing too definitely at a specific category of individuals/ aliens, exceeding the legal requirement of equal treatment.

\footnotetext{
88) Draft bill 32 2001/02, referring to commission report (betenkning) 1982/968.

89) Art. 3 in the European Convention on Human Right.

90) Individuals who cannot be sent back to their country origin on account of the non-refoulement principle can stay on a "tolerated residence" (talt ophold) in Denmark. This is not a residence permit as it does not involve any right to integration, work or social assistance; it is the same kind of residence applied to rejected asylum seekers that cannot be sent out because of risk of torture or death penalty, but who nonetheless do not fall within the legal notion of refugee.

91) Section 19 (3) of the Aliens Act.

92) See chapter 5 in circular CIS nr. 9 of 12/01/2006 on the administrative guidelines in applications for citizenship.

93) Section 8 B in the Citizenship Consolidation Act 422 of 07/06/2004.

94) Violation of the Parts 12 and/or 13 in the Danish Criminal Code (danger for or threat to national security and public order, safety or health).
} 


\section{Conclusions}

This article has described the legal backdrop against which the "cartoon crisis" developed. A few concluding remarks will focus primarily on the effects of the policies most recently introduced which presently form part of the everyday life of the foreigner citizens of Denmark. As I claimed in the introduction, the evaluation of the regulations in force in the area of migrants' legal status points in three different directions.

First, there is evidence in the legal texts to suggest that the subjects involved in the cartoon controversy may have experienced difference of treatment and stigmatisation in the polity. The recent changes (in 2002 and 2004) in the rules for family reunification and visa-requirement for third-country nationals and the new procedures against terrorism have carried with them a symbolic aspect of closure of the Danish society towards foreigners. The basically positive appeal to integration in the labour market is often coupled to punitive measures, which can be perceived negatively by the recipients. The fact that the newest changes affect directly only a group of nationals, to be more precise third-country nationals, have the unfortunate consequence of affecting not only a migrant group but also a religious group. It may be discussed whether these lawfully introduced regulations may sometime lack the broader perspective of the long term consequences of these legislative actions.

Second and directly connected to the first argument, citizenship is a key factor in the assessment of the migrants' status in Denmark. Depending on the nationality of the alien, different sets of rules apply concerning the permission to enter and/or stay in the country, in case with/without a visa, possibility for engaging in a working activity, prospects of family reunification, the obligation to follow an integration course and so on. Progressive developments concerning the simplification of access to these rights for migrants have been introduced in Danish law as a consequence of international cooperation, which may speak for an intensified introduction of international legal instruments in order to ensure a high level of human rights protection. Here, I think especially about the right of free movement for European citizens that has developed in EU-law and is in force in the Member States.

Third, the existence of multiple intertwined acts of regulation does not always foster transparency in the legal practice. For example, the conditions to be met to be able to marry as a foreigner in Denmark are by now so various that exploitations of legal gaps and unclear administration may occur. This poses a serious threat to the principle of equality of treatment of citizens living in the same territory and theoretically subjected to the same regulations, even if they do not share the same nationality. 